\title{
Path Analisis Technology Acceptance Model pada Penerapan Blended Learning
}

\author{
Wawan Laksito Yuly Saptomo ${ }^{1)}$, Elistya Rimawati ${ }^{2}$ \\ 1) Program Studi Informatika, STMIK Sinar Nusantara \\ Jl. KH. Samanhu No. 84-86 Laweyan, Surakarta, Jawa Tengah \\ wlaksito@sinus.ac.id \\ ${ }^{2)}$ Program Studi Sistem Informasi, STMIK Sinar Nusantara \\ J1. KH. Samanhu No. 84-86 Laweyan, Surakarta, Jawa Tengah \\ elistyarimawati@gmail.com
}

\begin{abstract}
Abstrak
Model pembelajaran Blended Learning adalah sistem pembelajaran yang menggabungkan pembelajaran secara tatap muka di kelas secara offline dengan pelaksanaan pembelajaran secara online. Penelitian ini bertujuan untuk mengukur tingkat penerimaan dan perilaku peserta didik terhadap teknologi dari model pembelajaran Blended Learning. Variabel yang dikembangkan merujuk pada Technology Acceptance Model (TAM), yaitu model penerimaan pengguna teknologi terhadap sistem informasi. Model ini dikembangkan untuk menjelaskan bahwa perilaku pengguna sistem berdasarkan pada rasa percaya, sikap, keinginan, dan kenyataan perilaku pengguna. Data yang diperoleh dianalisis hubungan jalur (path) hubungan variabel dengan Structural Equation Modeling (SEM) menggunakan metode Partial Least Square (PLS). Hasil Analisa PLS dan Boostraping menunjukkan nilai Pengaruh Langsung, Pengaruh Tidak Langsung, dan Pengaruh tidak langsung sesuai jalur spesifikasi melalui variabel intervening (Spesific Indirect Efect).
\end{abstract}

Kata kunci: Blended Learning, Path analysis, TAM, PLS

\begin{abstract}
Blended Learning Model is a system that collaborates in face-to-face learning with online learning. This study aims to measure the level of acceptance and behavior of students towards technology from the Blended Learning model. Variable development refers to the Technology Acceptance Model (TAM). TAM is model of information systems user acceptance. The TAM model is developed from psychological theories that explain the user system based on user thruth, user attitudes, user desires, and real behaviors. Path analysis uses Structural Equation Modeling (SEM). Data analysis uses the Partial Least Square (PLS) method. Based on the results of the PLS and Boostraping analysis the values of Direct Effect, Indirect Effect, and Spesific Indirect Effect.
\end{abstract}

Keywords: Blended Learning, Path analysis, TAM, PLS

\section{PENDAHULUAN}

Pada Era revolusi industry 4.0, perkuliahan secara daring merupakan tantangan apalagi di tengah pandemi. Sejak pandemi Covid-19, adaptasi pola hidup dan pola kerja terhadap kondisi kebiasaan baru adalah suatu keniscayaan, termasuk metoda dan cara pembelajaran. Dominasi ruang belajar secara daring menjadi lebih besar dibandingkan ruang belajar tatap muka langsung (luring). Blended learning yang dulunya ruang utamanya adalah tatap muka langsung dikelas dan ruang online sebagai pendukung atau suplemen pembelajaran harus dibalik (Flipped Clasroom). Banyak tantangan yang muncul dalam proses adaptasi model pembelajaran tersebut. Disparitas 
ketersediaan sarana, penguasaan teknologi antara pendidik dengan para peserta didik, perubahan perilaku belajar dan tempat belajar merupakan tantangan dalam proses pembelajaran bagi guru dan siswa. Guru dan siswa dituntut untuk beradaptasi terhadap model pembelajaran daring.

Tantangan tersebut menuntut perubahan pada pendidikan. Perlu penyesuaian sistem pembelajaran dengan integrasi objek fisik, objek digital, dan pembelajarnya. Faktor organisasi, manusia, dan teknologi, berkorelasi positif (searah) serta signifikan terhadap net benefit [1]. Keberadaan teknologi informasi dan komunikasi menjadikan sifat pekerjaan, cara kita belajar, dan makna hubungan sosial telah berubah [2]. Pembelajaran yang mengintegrasikan proses pembelajaran dengan pemanfaatan teknologi membuat proses pembelajaran dapat dilaksanakan tanpa batas ruang dan batas waktu dan berlangsung secara kontinu.

Pembelajaran secara online dapat memberikan kemudahan bagi pembelajar, aktifitas pembelajaran dapat dilakukan secara lebih fleksibel tempat (di mana saja) dan waktu (kapan saja). Akan tetapi pembelajar sebagai manusia (makhluk sosial) tetap memiliki hasrat untuk berada dalam suatu komunitas yang sesungguhnya. Komunitas pembelajaran secara nyata (offline) tetap dipandang penting dalam pembelajaran. Walaupun perannya tidak dominan sebagaimana dalam paradigma mengajar, sosok pengajar tetap dibutuhkan untuk membina perilaku atau sikap yang berorientasikan norma-norma di masyarakat. Dalam Blended Learning masing-masing karakter terbaik dari pembelajaran tatap muka secara offline dan pembelajaran secara online digabungkan. Pendidik maupun peserta didik akan mendapatkan dua keuntungan dari model Blended Learning. Proses pembelajaran dapat dirasakan melalui "keberagaman instruksi" (differentiated instruction ) dan "kenyamanan dan kehadiran" (pacing and attendance). Keberagaman instruksi melibatkan pembelajaran yang dirancang untuk peserta didik. Berdasarkan tingkat kesulitan materi belajar, pengajar akan memformulasikan dan menentukan materi belajar, capaian pembelajaran, serta kemampuan akhir yang diharapkan dapat dikuasai oleh peserta didik. Berdasarkan minat belajar serta gaya belajar peserta didik, lingkungan dan aktivitas pembelajaran bisa diberikan secara tatap muka dan secara online. Kenyamanan dan kehadiran, peserta didik secara mandiri bisa menentukan kapan saatnya belajar berdasarkan kondisi individual masingmasing [3]. Selain peserta didik bisa mendapatkan pembelajaran secara tatap muka secara offline dengan dosen/guru di dalam kelas, mereka juga bisa mencari dan mendapatkan materi yang diberikan secara online, di manapun mereka berada sehingga metode ini dirasa sangat efisien dan fleksibel.

Blended learning mempunyai karakter yang fleksibel serta efektif dan efisien sehingga model pembelajaran ini sangat cocok bagi generasi $\mathrm{Z}$ yang berkarakter menyukai hal-hal yang bersifat instan. Tetapi perlu diperhatikan bahwa pengetahuan mereka terhadap penggunaan dan pemanfaatan teknologi informasi sangat berbeda-beda. Sebagaian dari mereka bukan pengguna teknologi tetapi hanya sebatas pada pengguna gadget [4]. Tiap peserta didik mempunyai pengalaman yang berbeda-beda. Tingkat pengalaman dan pemahaman peserta didik terhadap suatu objek teknologi dipengaruhi oleh kehidupan keluarga, masyarakat dan lingkungan sebelumnya. Penerapkan metode yang tepat dalam kegiatan pembelajaran harus disesuaikan dengan karakter para peserta didiknya. Kesesuaian karakter peserta didik dengan metoda pembelajaran akan mempengaruhi penerimaan terhadap metoda tersebut, yang pada akhirnya dapat meningkatkan efektifitas dalam mencapai tujuan pembelajaran. Peserta didik sebagai subyek pembelajar mempunyai persepsi dalam penerimaan teknologi.

Pengembangan blended learning tentunya didasarkan atas kebutuhan dan persepsi pembelajar. Persepsi pembelajar terhadap faktor-faktor penerapan blended learning dapat digunakan dalam memilih dan menentukan strategi penerapannya. Diperlukan kajian terhadap faktor-faktor kemudahan dan manfaat teknologi dan pengaruhnya terhadap penerimaan pembelajar. Penerimaan pembelajar dapat dilihat dari sikap, keinginan dan perilaku nyata terkait dengan penerapan blended learning. Penelitian ini akan menguji faktor-faktor apa saja yang mempengaruhi penerimaan siswa terhadap metoda Blended Learning dengan mengadaptasi Technology Acceptance Model (TAM). 


\section{TINJAUAN PUSTAKA}

Model penerimaan teknologi (Technology Acceptance Model atau TAM) merupakan suatu model penerimaan sistem teknologi informasi yang akan digunakan oleh pemakai. Model penerimaan teknologi atau Technology Acceptance Model (TAM) dikembangkan berdasarkan model Teory of Reasoned Action (TRA) [5]. Model Teory of Reasoned Action (TRA) menunjukkan bahwa sikap (attitude) seseorang digabung dengan norma-norma subjektif (subjective norms) akan mempengaruhi minat (behavioral intention) dan akhirnya akan menentukan perilaku (behavior) seseorang. Model Teory of Reasoned Action (TRA) dapat diterapkan karena keputusan yang dilakukan oleh individu untuk menerima suatu teknologi sistem informasi merupakan tindakan sadar yang dapat dijelaskan dan diprediksi oleh minat perilakunya [5].

Online learning mendukung terwujudnya pemerataan serta peningkatan kualitas pendidikan. Akses teknologi yang semakin luas dan kesesuaian pemanfaatan teknologi dapat merealisasikan pendidikan yang menghasilkan peserta didik yang memiliki kompetensi abad 21. Penelitian penggunaan E-learning di SMA Kota Jambi menyimpulkan bahwa E-learning dapat mendorong keaktifan dan hasil belajar peserta didik. Peningkatan rata-rata aktivitas $34,84 \%$, peningkatan rata-rata hasil belajar 32\%, peningkatan ketuntasan adalah 38,84\% [4]. Bagi Peserta didik, model pembelajaran e-learning meningkatkan minat belajar. Proses belajar dirasa lebih menarik karena memanfaatkan teknologi yang sesuai dengan gaya hidup mereka keseharian. Karena interaksi pembelajaran terjalin secara aktif antara para peserta didik dengan pendidik maka kegiatan belajar tidak membosankan. Pembelajaran bermodel E-learning secara signifikan memberikan pengaruh terhadap hasil belajar siswa. E-learning berbasis web berdampak pada motivasi belajar peserta didik. Peserta didik menjadi lebih bersemangat untuk mencari dan menemukan objek belajar. Peserta didik juga lebih dapat berpikir kritis dan logis. Namun demikian aktifitas belajar peserta didik secara online di luar jam pelajaran mengalami penurunan. Penurunan tersebut akibat faktor teknis dan non-teknis [5]. Bagi pendidik yang berdedikasi serta memiliki tanggung jawab yang tinggi terhadap mutu pembelajaran, akan menjadikan model tersebut sebagai peluang dalam meningkatkan kompetensi pribadi serta akan melakukan pengembangan dan inovasi pembelajaran [4].

\section{METODE PENELITIAN}

\subsection{Pendekatan Penelitian}

Penelitian ini menggunakan pendekatan kuantitatif. Pendekatan kuantitatif ini menggunakan angka dalam bentuk skor sebagai dasar analisis. Data diambil dengan survey menggunakan kuesioner. Data yang dikaji adalah data sampel yang diambil dari populasi. Dalam hal ini, survey dimaksudkan untuk mempelajari persepsi, sikap, dan perilaku yang diperlukan dalam tujuan penelitian. Berdasarkan data tersebut, fakta atau informasi yang diperoleh dapat menggambarkan kondisi masing-masing variabel yang diteliti. Dari kondisi masing-masing variabel dimungkinkan untuk mengetahui pengaruh atau atau kelompok variabel dengan variabel lainnya.

\subsection{Responden}

Populasi dalam penelitian ini adalah peserta didik, yang telah menerima pembelajaran secara Blended Learning dengan durasi waktu minimal 1 (satu) semester. Media pembelajaran online menggunakan Google Classroom. Dalam penelitian ini, pengambilan sampel menggunakan teknik proportionate stratified random sampling. Teknik ini merupakan teknik untuk populasi penelitian yang berstrata secara proporsional serta tidak homogen [6]. Penyebaran kuesioner dengan menggunakan kuesioner secara online yang ditautkan di E-learning. Ukuran sampel minimum apabila model yang dianalisis ada lebih dari sama dengan 5 konstruk, dimana setiap konstruk dilakukan pengukuran dengan setidaknya 3 indikator, maka jumlah sampel adalah 100 sampai dengan 300 pengamatan [7]. Dalam penelitian ini ada 5 konstruk dengan data diambil dari responden sejumlan 288 orang. 


\subsection{Pengumpulan Data}

Data dikumpulkan dengan teknik pengumpulan data kuesioner. Seperangkat formulir peryataan atau pertanyaan tertulis disediakan untuk mendapatkan informasi dari beberapa responden. Pertanyaan dalam kuesioner ini berbentuk pertanyaan tertutup yang didesain untuk mendapatkan data tentang kondisi yang dialami para responden. Indikator-indikator variabel direpresentasikan pada pertanyaan-pertanyaan dalam kuesioner. Pengukuran jawaban menggunakan skala Linkert dari nilai 1 sampai dengan 5.

\subsection{Desain Penelitian}

Besar pengaruh dan kontribusi variabel-variabel dalam Technology Acceptance Model (TAM) adalah hal menjadi tujuan penelitian ini. Kontruk TAM terdiri dari persepsi kebermanfaatan (perceived usefulness), persepsi kemudahan penggunaan (perceived ease of use), sikap pengguna (attitude toward using), niat berperilaku (behavioral intention), dan perilaku nyata pengguna (actual usage). Model dapat dibedakan menjadi dua bagian yaitu kepercayaan dan penerimaan. Kepercayaan terdiri atas variabel persepsi kebermanfaatan (perceived usefulness) dan persepsi kemudahan penggunaan (perceived ease of use), adapun penerimaan terdiri dari variabel sikap pengguna (attitude toward using), niat berperilaku (behavioral intention), serta perilaku nyata pengguna (actual usage) [8]. Hubungan antar konstruk diperlihatkan pada Gambar 1.

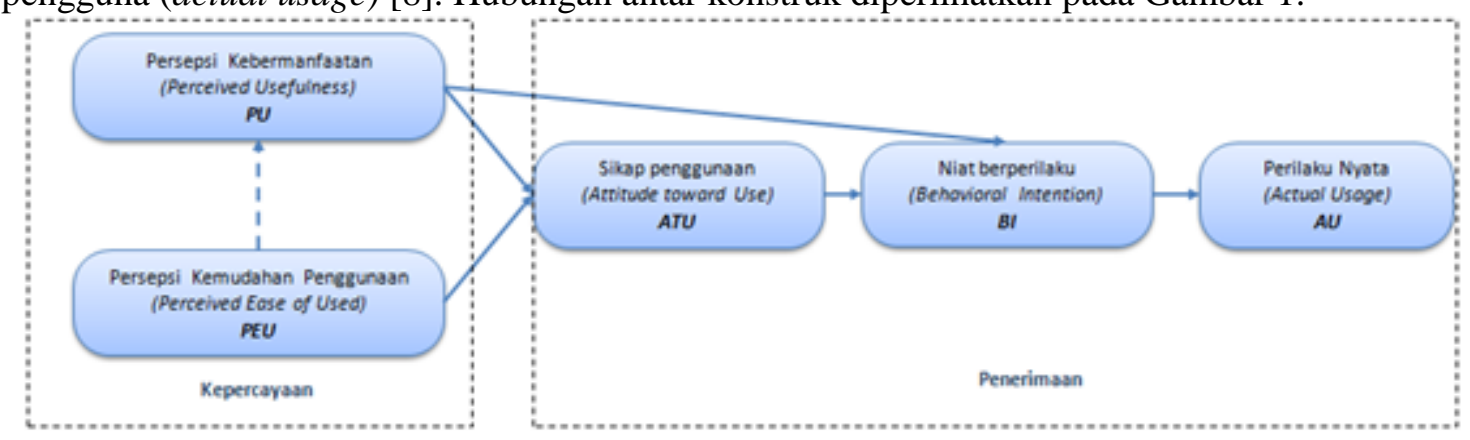

Gambar 1. Technology Acceptance Model

Desain penelitian pada Gambar 1 mengambil bentuk model structural yang merupakan bagian dari model SEM (Structure Equation Model) yang menggambarkan bentuk hubungan korelasi antara variabel-variabel laten dalam model penelitian. Pengujian model structural bertujuan untuk mengetahui jenis hubungan apa yang ada di bagian variabel yang membangun model.

\subsection{Analisis Data}

Berdasarkan kerangka teori, dalam penelitian ini menggunakan metoda analisis pemeriksaan kuantitatif, menggunakan Structural Equation Modeling (SEM). SEM menggunakan pendekatan analisis terhadap faktor, analisis model struktural, dan analisis jalur berbasis variance yang dikenal sebagai metode Partial Least Square (PLS). Partial least square ini adalah suatu metoda statistik multivariat. PLS dapat digunakan untuk menganalisis banyak variabel respon dan variabel eksplanatori sekaligus. Metode ini bersifat lebih robust atau kebal artinya parameter model tidak banyak berubah saat sampel baru diambil sehingga untuk metode analisis regresi berganda dan regresi komponen utama analisis ini adalah alternatif yang baik [9].

\section{PEMBAHASAN}

Persyaratan asumsi distribusi tertentu tidak dipersyaratkan dalam metode PLS, maka tidak diperlukan teknik parametric untuk menguji signifikansi. Evaluasi model PLS didasarkan pada prediksi yang bersifat non-parametrik. Evaluasi model PLS melalui evaluasi model pengukuran indikator (outer model) dan evaluasi model structural (inner model). Evaluasi outer model untuk menilai validitas serta reliabilitas model. Validitas convergent dan discriminant dari indikator pembentuk konstruk laten digunakan untuk mengevaluasi Outer model dengan indikator reflektif. 
Pada Blok indikatornya dievaluasi composite reliability dan cronbach alpha [10]. Prediksi hubungan antar variabel laten di evaluasi dengan Inner Model, yaitu dengan melihat besarnya presentase varian (nilai $R$-Square) pada konstruk laten endogen.

\subsection{Evaluasi Model Pengukuran (Outer Model)}

Pengukuran validitas dan realibilitas untuk memastikan kelayakan alat ukur maka dilakukan evaluasi outer model. Ada beberapa indikator yang digunakan untuk analisa outer model yaitu (1) Convergent validity, (2) Discriminant Validity, (3) Reliability [9]. Convergent validity diukur dengan melihat nilai loading factor (LV) dan average variance extracted (AVE). Discriminant Validity dilihat dari nilai akar kuadrat $A V E$. Pengukuran Reliability konstruk dilakukan dengan mengukur Cronbach's Alpha (CA) atau Composite Reliability (CR). Nilai Loading Factor (LV), Cronbach's Alpha (CA), Composite Reliability (CR), Average Variance Extracted (AVE) diperlihatkan pada Tabel 1.

Tabel 1. Loading Factor (LV), Cronbach's Alpha (CA), Composite Reability (CR), Average Variance

\begin{tabular}{|c|c|c|c|c|c|}
\hline Varabel Laten & Indikator (Konstruk) & LF & $\mathrm{CA}$ & $\mathrm{CR}$ & AVE \\
\hline Kemudahan & Kemudahan Dipelajari (X1.1-PEU1) & 0.707 & 0.824 & 0.872 & 0.534 \\
\hline Penggunaan & Syarat keahlian pengguna (X1.2-PEU2) & 0.658 & & & \\
\hline \multirow[t]{4}{*}{ (PEU) } & Kemudahan interaksi (X1.3-PEU3) & 0.756 & & & \\
\hline & Fleksibilitas waktu dan tempat (X1.4-PEU4) & 0.678 & & & \\
\hline & Fleksibilitas alat yang dipakai (X1.5-PEU5) & 0.744 & & & \\
\hline & Kemudahan cara penggunaan (X1.6-PEU6) & 0.828 & & & \\
\hline Persepsi & Kecepatan penerimaan informasi (X2.1-PU1) & 0.750 & 0.797 & 0.860 & 0.552 \\
\hline Kemanfaatan & Kemudahan interaksi peserta pembelajaran (X2.2-PU2) & 0.718 & & & \\
\hline \multirow[t]{3}{*}{ (PU) } & Kuantitas materi pembelajaran (X2.3-PU3) & 0.739 & & & \\
\hline & Kemudahan pengerjaan tugas (X2.4-PU4) & 0.735 & & & \\
\hline & Pencapaian tujuan belajar (X2.5-PU5) & 0.771 & & & \\
\hline Sikap & Kesenangan terhadap pembelajaran (Y1.1-ATU1) & 0.882 & 0.882 & 0.919 & 0.741 \\
\hline Penggunaan & Kenyamanan dalam belajar (Y1.2-ATU2) & 0.900 & & & \\
\hline \multirow[t]{2}{*}{ (ATU) } & Kepuasan terhadap sistem pembelajaran (Y1.3-ATU3) & 0.868 & & & \\
\hline & Penerimaan sistem pembelajaran (Y1.4-ATU4) & 0.788 & & & \\
\hline \multirow{4}{*}{$\begin{array}{l}\text { Niat Berperilaku } \\
\text { (BI) }\end{array}$} & Motivasi penggunaan sistem pembelajaran (Y2.1-BI1) & 0.799 & 0.811 & 0.876 & 0.638 \\
\hline & Motivasi penyediaan sarana (Y2.3-BI2) & 0.820 & & & \\
\hline & Rekomendsi kepada matakuliah/dosen lain (Y2.4-BI3) & 0.817 & & & \\
\hline & Rekomendasi kepada peserta didik lain (Y2.5-BI4) & 0.757 & & & \\
\hline \multirow{4}{*}{$\begin{array}{l}\text { Perilaku Nyata } \\
\text { (AU) }\end{array}$} & Frekuensi penggunaan media pembelajaran (Y3.1-AU1) & 0.672 & 0.765 & 0.847 & 0.583 \\
\hline & Durasi penggunaan media pembelajaran (Y3.4-AU2) & 0.666 & & & \\
\hline & Tujuan mendapatkan informasi perkuliahan (Y3.5-AU3) & 0.862 & & & \\
\hline & Tujuan kepentingan tugas perkuliahan (Y3.6-AU4) & 0.834 & & & \\
\hline
\end{tabular}

\subsubsection{Convergent Validity}

Convergent validity terkait dengan tingkat korelasi antara pengukur-pengukur konstruk yang semestinya berkorelasi tinggi. Nilai convergen validity merupakan nilai loading factor (LV) konstruk laten dengan indikator-indikatornya. Aturan untuk menilai convergent validity yang biasa digunakan yaitu nilai loading factor lebih besar dari 0.7 untuk penelitian yang bersifat confirmatory. Pada penelitian yang bersifat explanatory, nilai antar 0.6 sampai dengan 0.7 dapat diterima. Nilai average variance extracted (AVE) diharuskan lebih dari 0.5 [10].

Pada kolom LF Tabel 1 diperlihatkan nilai loading factor indikator dengan konstruknya pada penelitian ini semua bernilai >0.6, sehingga nilai-nilai loading factor layak untuk dijadikan pengukuran. Convergent validity juga ditunjukan dari nilai AVE masing masing konstruk $>0.5$ seperti diperlihatkan pada kolom AVE Tabel 1. Dari nilai-nilai tersebut menunjukkan bahwa indikator-indikator berkorelasi tinggi terhadap konstruknya.

\subsubsection{Discriminant Validity}

Discrimant validity berhubungan dengan manifes konstruk yang berbeda semestinya tidak berkorelasi tinggi. Indikator reflektif dilakukan pengujian validitas diskriminan dengan 
membandingkan nilai korelasi antar konstruk dalam model dengan akar kuadrat dari AVE pada setiap konstruk. Validitas baik ditunjukkan dari akar kuadrat AVE pada setiap konstruk harus lebih besar dari korelasi antar konstruk [11].

Tabel 2. Akar Kuadrat AVE (kriteria Fornell-Larcker)

\begin{tabular}{cccccc}
\hline & ATU & AU & BI & PEU & PU \\
\hline ATU & $\mathbf{0 . 8 6 1}$ & & & & \\
AU & 0.474 & $\mathbf{0 . 7 6 4}$ & & & \\
BI & 0.719 & 0.546 & $\mathbf{0 . 7 9 9}$ & & \\
PEU & 0.612 & 0.476 & 0.567 & $\mathbf{0 . 7 3 1}$ & \\
PU & 0.741 & 0.494 & 0.633 & 0.669 & $\mathbf{0 . 7 4 3}$ \\
\hline
\end{tabular}

Dari Tabel 2 terlihat bahwa nilai-nilai akar kuadrat AVE dari konstruk ATU lebih besar dari korelasi atara ATU dengan konstruk lainnya, yaitu AU, BI, PEU, PU. Nilai akar kuadrat AVE dari konstruk AU lebih besar dari korelasi atara AU dengan konstruk lainnya, yaitu ATU, BI, PEU, PU. Nilai akar kuadrat AVE dari konstruk BI lebih besar dari korelasi atara BI dengan konstruk lainnya, yaitu ATU, AU, PEU, PU. Nilai akar kuadrat AVE dari konstruk PEU lebih besar dari korelasi atara PEU dengan konstruk lainnya, yaitu ATU, AU, BI, PU. Sedang Nilai akar kuadrat AVE dari konstruk PU lebih besar dari korelasi atara PU dengan konstruk lainnya, yaitu ATU, AU, BI, PEU.

Berdasarkan hasil pengujian dimana akar kuadrat AVE untuk setiap konstruk lebih besar dari korelasi antar konstruk dalam model maka pengukuran memenuhi discriminant validity yang berarti setiap kontruk tidak berkorelasi tinggi terhadap konstruk lainnya.

\subsubsection{Reliability}

Pembuktikan intrumen dalam hal akurasi, konsistensi, dan ketepatan pada pengukuran konstruk dilakukan dengan pengujian reliabilitas. Pada PLS pengukuran reliabilitas konstruk dilakukan dengan mengukur Cronbach's Alpha (CA) atau Composite Reliability (CR) (DillonGoldstein's rho). Data yang memiliki nilai Cronbach's Alpha atau Composite Reliability lebih dari 0.7 mempunyai reliabilitas yang tinggi. Hasil pengujian reliabilitas ditunjukkan pada Tabel 1.

Nilai Cronbach's Alpha setiap konstruk > 0.7 (PEU $=0.824 ; \mathrm{PU}=0.797 ;$ ATU $=0.882$; $\mathrm{BI}=0.811 ; \mathrm{AU}=0.765$ ). Nilai Composite Reliability setiap konstruk $>0.7$ (PEU $=0.872$; $\mathrm{PU}=0.860 ; \mathrm{ATU}=0.919 ; \mathrm{BI}=0.876 ; \mathrm{AU}=0.847$ ). Dari nilai Cronbach's Alpha serta Composite Reliability menunjukkan bahwa instrument yang digunakan memiliki reliabilitas yang tinggi.

\subsection{Evaluasi Model Struktural (Inner Model)}

Evaluasi model struktural dimulai dengan melihat kekuatan prediksi. Nilai $R$-Squares $\left(\mathrm{R}^{2}\right)$ untuk setiap variabel laten endogen dilihat untuk mengukur kekuatan prediksi model. Tabel 3 memperlihatkan nilai $R^{2}>0$ dan $R^{2}>R^{2}$-dituju, hal tersebut menunjukkan ada pengaruh dari variabel laten endogen sesuai dengan garis pengaruh pada model.

Tabel 3. R-Squares

\begin{tabular}{lcc}
\hline \multicolumn{1}{c}{ Variabel } & R Square & R Square Adjusted \\
\hline PU-Persepsi Kemanfaatan & 0.447 & 0.445 \\
ATU-Sikap Penggunaan & 0.574 & 0.571 \\
BI-Niat Berperilaku & 0.539 & 0.536 \\
AU-Perilaku Nyata & 0.298 & 0.296 \\
\hline
\end{tabular}

Pengujian Inner model juga dapat dilihat dari nilai Goodness of Fit (GoF). Indeks Goodness of Fit (GoF) adalah rata-rata geometrik dari komunalitas rata-rata dan $\mathrm{R}^{2}$ rata-rata untuk semua konstruk endogen. Ini dapat digunakan untuk menentukan kekuatan prediksi keseluruhan dari model dengan memperhitungkan kinerja parameter pengukuran dan struktural. Goodness of Fit $(G o F)$ dihitung dengan rumus (1). Indeks GoF dibatasi antara 0 dan 1. Karena sifat deskriptif 
indeks GoF, tidak ada kriteria berdasarkan inferensi untuk menilai signifikansi statistiknya. Namun batas nilai berikut $(\mathrm{GoF}$ lemah $=0.1, \mathrm{GoF}$ moderat $=0.25$ dan $\mathrm{GoF}$ kuat $=0.36)$ dapat berfungsi sebagai garis dasar untuk memvalidasi model kompleks berbasis PLS secara umum [11].

$G o F=\sqrt{\overline{A V E} \times \overline{R^{2}}}$

Berdasarkan data AVE pada Tabel 1 dan $\mathrm{R}^{2}$ pada Tabel 3 dan dihitung menggunakan rumus (1) diperoleh nilai GoF sebesar 0.532 yang melebihi nilai cut-off 0,36 untuk kuat. Ini menunjukkan bahwa model memiliki kekuatan prediksi yang lebih baik dibandingkan dengan baseline nilai (kriteria GoF). Temuan ini cukup memvalidasi model PLS kompleks secara umum. Dari pengujian $\mathrm{R}^{2}$ dan $\mathrm{GoF}$ terlihat bahwa model yang dibentuk adalah robust. Sehingga pengujian hipotesa dapat dilakukan.

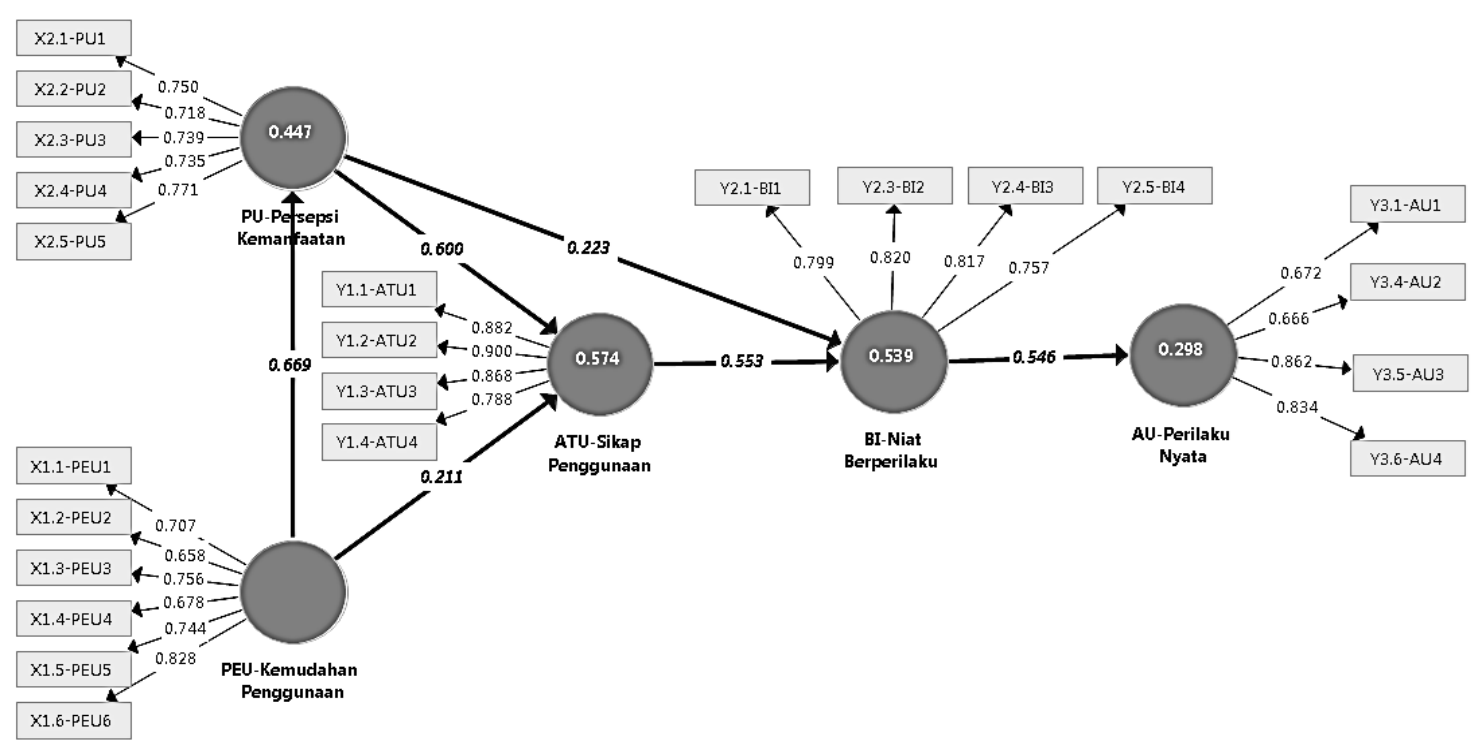

Gambar 2. Jalur variabel dengan nilai indicator, $\mathrm{R}^{2}$, serta koefisien jalur

Secara lengkap hubungan jalur variabel dengan nilai indicator, $\mathrm{R}^{2}$, serta koefisien jalur diperlihatkan pada Gambar 2.

\subsection{Analisa Pengaruh dan Jalur}

Berdasarkan hasil Analisa PLS dan Boostraping didapatkan nilai pengaruh Langsung (Direct Effect), Tidak Langsung (Indirect Effect), serta Pengaruh sesuai jalur spesifikasi melalui variabel intervening (Spesific Indirect Effect). Total Pengaruh merupakan penjumlahan dari nilai Pengaruh Langsung dan Total Pengaruh tidak Langsung, seperti diperlihatkan pada Tabel 4. Tabel 4 memperlihatkan total efek jalur dua buah variabel-variabel (sesuai model), efek interfensi suatu variabel terhadap pengaruh jalur dua buah variabel, efek tidak langsung dari jalur variabel, efek langsung jalur dua buah variabel, dan total efek suatu variabel terhadap variabel lainnya.

Tabel 4. Specific Indirect Effects, Indirect Effect, Direct Effect, Total Effect

\begin{tabular}{|c|c|c|c|c|c|c|}
\hline \multirow{2}{*}{$\begin{array}{c}\text { Jalur } \\
(1)\end{array}$} & \multicolumn{2}{|l|}{ SIE Intervining } & \multirow{2}{*}{$\begin{array}{c}\text { IE } \\
(4)=\sum(3)\end{array}$} & \multirow{2}{*}{$\begin{array}{l}\text { DI } \\
(5)\end{array}$} & \multirow{2}{*}{$\begin{array}{l}\text { Total Effect } \\
(6)=(4)+(5)\end{array}$} & \multirow{2}{*}{$\begin{array}{c}\mathrm{P} \\
\text { Values }\end{array}$} \\
\hline & (2) & (3) & & & & \\
\hline$A T U \rightarrow A U$ & $A T U \rightarrow \boldsymbol{B I} \rightarrow A U$ & 0.302 & 0.302 & - & 0.302 & 0.000 \\
\hline$A T U \rightarrow B I$ & - & & - & 0.553 & 0.553 & 0.000 \\
\hline$B I \rightarrow A U$ & - & & - & 0.546 & 0.546 & 0.000 \\
\hline$P E U \rightarrow A T U$ & $P E U \rightarrow \boldsymbol{P U} \rightarrow A T U$ & 0.402 & 0.402 & 0.211 & 0.612 & 0.000 \\
\hline$P E U \rightarrow A U$ & $P E U \rightarrow A T U \rightarrow B I \rightarrow A U$ & 0.064 & 0.267 & - & 0.267 & 0.000 \\
\hline
\end{tabular}




\begin{tabular}{|c|c|c|c|c|c|c|}
\hline \multirow{5}{*}{$P E U \rightarrow B I$} & $P E U \rightarrow \boldsymbol{P U} \rightarrow \boldsymbol{A T U} \rightarrow \boldsymbol{B I} \rightarrow A U$ & 0.121 & \multirow{5}{*}{0.488} & \multirow{5}{*}{ - } & \multirow{5}{*}{0.488} & \multirow{5}{*}{$\mathbf{0 . 0 0 0}$} \\
\hline & $P E U \rightarrow \boldsymbol{P U} \rightarrow \boldsymbol{B I} \rightarrow A U$ & 0.082 & & & & \\
\hline & $P E U \rightarrow \boldsymbol{A T U} \rightarrow B I$ & 0.117 & & & & \\
\hline & $P E U \rightarrow \boldsymbol{P U} \rightarrow \boldsymbol{A T U} \rightarrow B I$ & 0.222 & & & & \\
\hline & $P E U \rightarrow \boldsymbol{P} \boldsymbol{U} \rightarrow B I$ & 0.149 & & & & \\
\hline$P E U \rightarrow P U$ & - & & - & 0.669 & 0.669 & 0.000 \\
\hline$P U \rightarrow A T U$ & - & & - & 0.600 & 0.600 & 0.000 \\
\hline$P U \rightarrow A U$ & PU->>BI->>AU & 0.303 & 0.303 & - & 0.303 & 0.000 \\
\hline PU -> BI & PU->>ATU->>BI & 0.332 & 0.332 & 0.223 & 0.555 & 0.000 \\
\hline
\end{tabular}

Berdasarkan nilai Total Pengaruh dan status signifikansi yang diperlihatkan pada Tabel 4, maka diperoleh informasi:

1. Kemudahan penggunaan berpengaruh positif terhadap kegunaan, dapat diartikan bahwa semakin baik kemudahan penggunaan maka kemanfaatan akan semakin baik juga.

2. Kemudahan penggunaan berpengaruh positif terhadap sikap pengguna, dapat diartikan bahwa semakin baik kemudahan penggunaan maka sikap pengguna akan semakin baik juga.

3. Kemudahan penggunaan berpengaruh positif terhadap niat berperilaku, dapat diartikan bahwa semakin baik kemudahan penggunaan maka sikap penggunakan akan semakin baik juga.

4. Kemudahan penggunaan berpengaruh positif terhadap perilaku nyata pengguna. Dapat diartikan bahwa semakin baik kemudahan penggunaan akan mendorong peserta didik untuk berperilaku menggunakan lebih sering, dengan durasi lebih lama, dan diperuntukan untuk meningkatkan pembelajaran.

5. Kegunaan berpengaruh positif terhadap sikap penggunaan, dapat diartikan bahwa semakin baik kemanfaatan maka sikap penggunaan akan semakin baik juga.

6. Kegunaan berpengaruh positif terhadap niat berperilaku, dapat diartikan bahwa semakin baik kemanfaatan maka niat berperilaku akan semakin meningkat.

7. Kegunaan berpengaruh positif terhadap perilaku nyata, dapat diartikan bahwa semakin baik kemanfaatan akan mendorong peserta didik untuk berperilaku menggunakan lebih sering, dengan durasi lebih lama, dan diperuntukan untuk meningkatkan pembelajaran.

8. Sikap penggunaan berpengaruh positif terhadap niat berperilaku, dapat diartikan bahwa semakin baik sikap penggunaan maka niat berperilaku akan semakin meningkat.

9. Sikap penggunaan berpengaruh terhadap perilaku nyata, dapat diartikan bahwa semakin baik sikap penggunaan akan mendorong peserta didik untuk berperilaku menggunakan lebih sering, dengan durasi lebih lama, dan diperuntukan untuk meningkatkan pembelajaran.

10. Niat berperilaku berpengaruh positif terhadap perilaku nyata, dapat bahwa semakin tinggi niat berperilaku maka perilaku nyata akan semakin baik pula.

\section{KESIMPULAN}

Penelitian analisis jalur (path) penerimaan Blended learning menggunakan model hubungan variabel penerimaan teknologi (Technology Acceptance Model (TAM)). Jalur hubungan variabel dianalisis dengan metoda analisis pemeriksaan kuantitatif, menggunakan Structural Equation Modeling- Partial Least Square (SEM-PLS).

Hasil penelitian menunjukkan variabel-variabel kepercayaan terhadap teknologi yang terdiri dari variabel kemanfaatan teknologi dan kemudahan penggunaan teknologi berpengaruh positif dan signifikan terhadap penerimaan teknologi Blended Learning. Penerimaan teknologi Blended Learning terkait dengan sikap niat berperilaku, dan perilaku nyata pembelajar. Dari hasil tersebut mnunjukkan bahwa penerapan Blended Learning perlu penguatan persepsi dan pemahaman teknologi kepada pembelajar. 


\section{DAFTAR PUSTAKA}

[1] F. Poluan, A. Lumenta, and A. Sinsuw, "Evaluasi Implementasi Sistem E-Learning Menggunakan Model Evaluasi Hot Fit: Studi Kasus Universitas Sam Ratulangi," EJournal Tek. Inform. Ratulangi, Univ. S A M Stud. Progr. Inform. Tek. Tek. Fak. Ratulangi, Univ. Sam Kampus, Jl Bahu, Unsrat, vol. 4, no. 2, pp. 1-6, 2014.

[2] Siti Zubaidah, "Keterampilan Abad Ke-21: Keterampilan Yang Diajarkan Melalui Pembelajaran," in Seminar Nasional Pendidikan, 2016, vol. 2, no. 2, pp. 1-17, doi: 10.1021/acs.langmuir.6b02842.

[3] W. L. Y. Saptomo, Ragam Media Interaktif Dalam Pembelajaran. Semarang: BPUNISBANK, 2018.

[4] A. Purnomo, N. Ratnawati, and N. F. Aristin, "Pengembangan Pembelajaran Blended Learning Pada Generasi Z," J. Teor. dan Praksis Pembelajaran IPS, vol. 1, no. 1, pp. 7076, 2016, doi: 10.17977/um022v1i12016p070.

[5] N. Marangunić and A. Granić, "Technology Acceptance Model: a literature review from 1986 to 2013," Univers. access Inf. Soc., vol. 14, no. 1, pp. 81-95, 2015.

[6] Sugiyono, Metode Penelitian Kuantitatif Kualitatif dan R\&D. Bandung: Alfabeta, 2012.

[7] G. D. Garson, Structural Equation Modeling. North Carolina: Statistical Associates Publishing, 2015.

[8] L. G. Wallace and S. D. Sheetz, "The Adoption of Software Measures: A Technology Acceptance Model (TAM) Perspective," Inf. Manag., vol. 51, no. 2, pp. 249-259, 2014.

[9] J. Henseler, C. M. Ringle, and M. Sarstedt, "Testing Measurement Invariance Of Composites Using Partial Least Squares," Int. Mark. Rev., vol. 33, no. 3, pp. 405-431, 2016, doi: https://doi.org/10.1108/IMR-09-2014-0304.

[10] F. H. J. Joe, S. Marko, H. Lucas, and G. K. Volker, "Partial Least Squares Structural Equation Modeling (PLS-SEM): An emerging tool in business research," Eur. Bus. Rev., vol. 26, no. 2, pp. 106-121, Jan. 2014, doi: 10.1108/EBR-10-2013-0128.

[11] J. Henseler and M. Sarstedt, "Goodness-of-Fit Indices for Partial Least Squares Path Modeling," Comput. Stat., vol. 28, no. 2, pp. 565-580, 2013, doi: 10.1007/s00180-0120317-1.

\section{Biodata Penulis}

Wawan Laksito Yuly Saptomo, lahir di Klaten tanggal 16 Juli 1970. Memperoleh gelar Sarjana.Sains pada Program Studi Matematika di Universitas Sebelas Maret pada tahun 1995 dan meraih gelar Magister Komputer di Universitas Dian Nuswantoro pada Tahu 2006. Menjadi dosen STMIK Sinar Nusantara Surakarta pada tahu 1995 sampai saat ini (2020).

Elistya Rimawati, lahir di Bantul tanggal 8 Oktober 1969. Memperoleh gelar Sarjana.Sains pada Program Studi Matematika di Universitas Sebelas Maret pada tahun 1996 dan meraih gelar Magister Sains Program Studi Manajemen di Universitas Islam Batik pada Tahu 2012. Menjadi dosen STMIK Sinar Nusantara Surakarta pada tahu 2003 sampai saat ini (2020). 